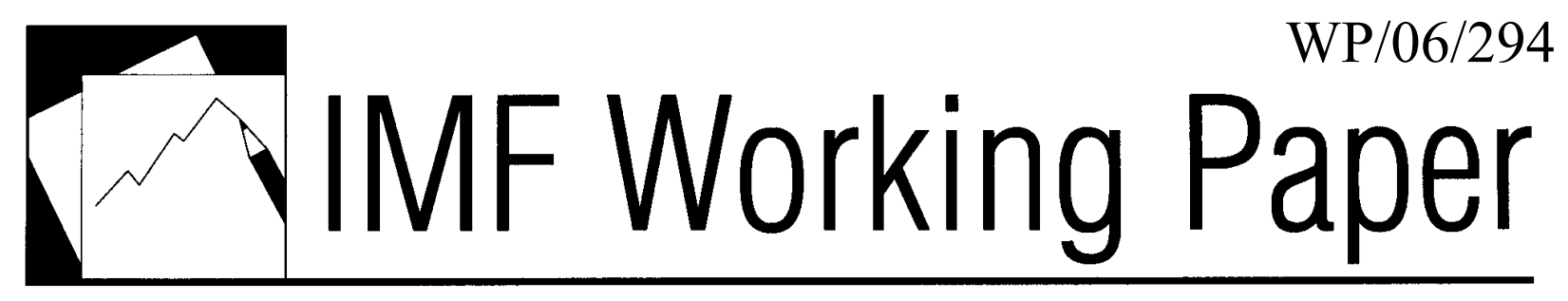

\title{
Effects of Globalization on Labor's Share in National Income
} Anastasia Guscina 



\title{
IMF Working Paper
}

Western Hemisphere Department

\section{Effects of Globalization on Labor's Share in National Income \\ Prepared by Anastasia Guscina ${ }^{1}$}

Authorized for distribution by Tamim Bayoumi

December 2006

\begin{abstract}
This Working Paper should not be reported as representing the views of the IMF. The views expressed in this Working Paper are those of the author(s) and do not necessarily represent those of the IMF or IMF policy. Working Papers describe research in progress by the author(s) and are published to elicit comments and to further debate.

The past two decades have seen a decline in labor's share of national income in several industrial countries. This paper analyzes the role of three factors in explaining movements in labor's share - factor-biased technological progress, openness to trade, and changes in employment protection - using a panel of 18 industrial countries over 1960-2000. Since most studies suggest that globalization and rapid technological progress (associated with accelerated information technology development) began in the mid-1980s, the sample is split in 1985 into preglobalization/pre-IT revolution and postglobalization/post-IT revolution eras.
\end{abstract}

The results suggest that the decline in labor's share during the past few decades in the OECD member countries may have been largely an equilibrium, rather than a cyclical, phenomenon, as the distribution of national income between labor and capital adjusted to capital-augmenting technological progress and a more globalized world economy.

JEL Classification Numbers:E01, F02, F16

Keywords: Labor's share, capital's share, globalization, productivity, trade, labor protection, bargaining power, compensation share, national income, employment share, Heckscher-Ohlin theorem

Authors' E-Mail Addresses: Aguscina@img.org, Anagush@gwu.edu

\footnotetext{
${ }^{1}$ International Monetary Fund and George Washington University. The author is indebted to Tamim Bayoumi and Kornélia Krajnyák from the Western Hemisphere Department of the International Monetary Fund for support, guidance, and encouragement in writing this paper. She also wants to thank Christopher Towe, Ratna Sahay, and IMF workshop participants for useful comments.
} 


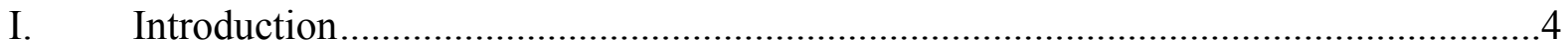

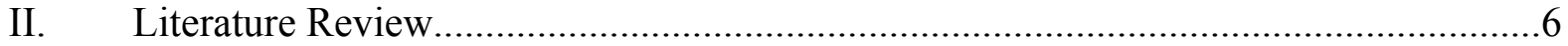

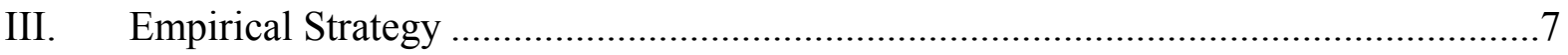

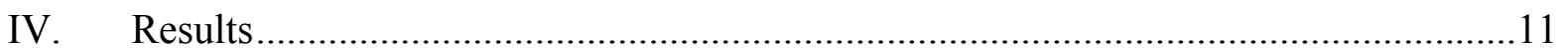

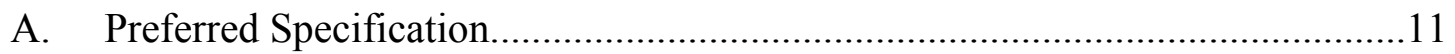

B. Robustness Checks.................................................................................13

Technology/productivity ......................................................................13

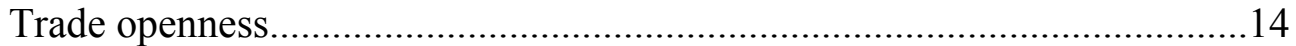

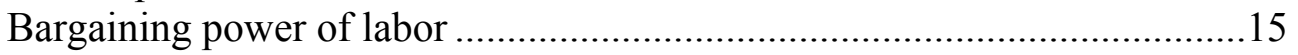

C. Are the Results a Strictly European Phenomenon? ............................................15

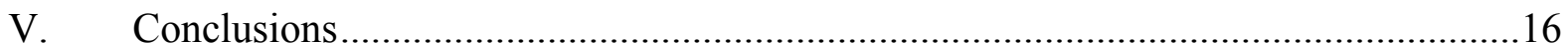

Appendices

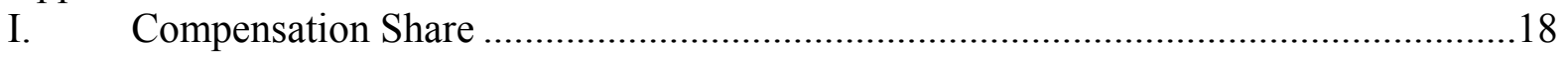

II. A First Pass at Data: Bivariate Regression Results .................................................20

III. Correlation Matrix of Explanatory Variables …………………..................................22

IV. Multivariate Regression Results for Alternative Specifications ..................................23

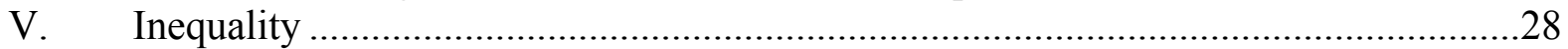

VI. Multivariate regression results for alternative specifications .....................................29

VII Capital-Augmenting Technological Progress ............................................................... 31

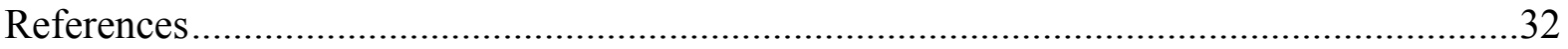

Figures

1. Cross-Country Average Labor Share in National Income ……................................... 4

2. Gini Coefficient in Mostly English-Speaking and Other Countries....................................... 8

3. Labor Share in Mostly English-Speaking and Other Countries.....................................

A1.1 Compensation Share: Actual and Fitted Values ......................................................18

Tables

1. Determinants of Labor's Share in National Income ..................................................12

A2.1 Results of Bivariate Regression: Compensation Share.....................................................22

A2.2 Results of Bivariate Regressions: Employment Share ……….....................................2

A3.1 Correlation Matrix of Explanatory Variables ............................................................22

A4.1 Compensation Share on Exports +Imports/GDP, Lagged Labor Productivity, Employment Protection. .......................................................................................... 23

A4.2 Employment Share: Exports+Imports/GDP, Lagged Labor Productivity,

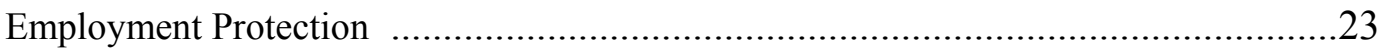

A4.3 Compensation Share: Trade Shares w/Dev. Countries, Labor Productivity, Employment Protection 
A4.4 Employment Share: Trade Shares w/Dev. Countries, Labor Productivity, Employment Protection

A4.5 Compensation Share: Exports+Imports/GDP, Productivity per Worker,

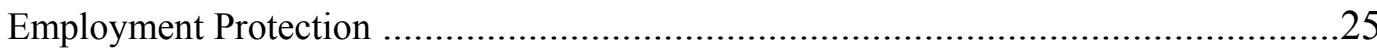

A4.6 Compensation Share: Trade Shares/wDev/Countries, Productivity per Worker, Employment Protection

A4.7 Compensation Share: Exports+Imports/GDP, Lagged labor Productivity, Union Density .26

A4.8 Compensation Share: Trade shares w/Dev Countries, Labor Productivity, Union Density,

A4.9 Compensation Share: FDI/GDP Ratio, Labor Productivity, Employment Protection .27

A5.1 Gini Coefficient on Openess, Productivity, Bargainng Power . .28

A6.1 Gini Coefficient on (Exports+Imports)/GDP, Lagged Labor Productivity, Employment Protection.

A6.2 Gini Coefficient on Trade Share w/Dev. Countries, Lagged Labor Productivity, Employment Protection.

A6.3 Gini Coefficient on FDI/GDP Ratio, Lagged Labor Productivity, Employment Protection

A6.4 Gini Coefficient on FDI/GDP Ratio, Lagged Labor Productivity per

Worker, Employment Protection 


\section{INTRODUCTION}

After rising steadily through the 1960s and 1970s, labor's share of national income in industrial countries experienced a decline in recent decades (Figure 1). Although temporary and cyclical factors may have played a role (such as wage restraint in response to slower growth and rapid increases in the stock market), the pervasiveness of the trend suggests that it may have also reflected structural changes. This paper analyzes the role of three such factors in explaining movements in labor's share over the years 1960-2000-factor-biased technological progress, openness to trade, and changes in employment protection.

Figure 1. Cross-Country Average Labor's Share in National Income (Ratio of labor income to national income)

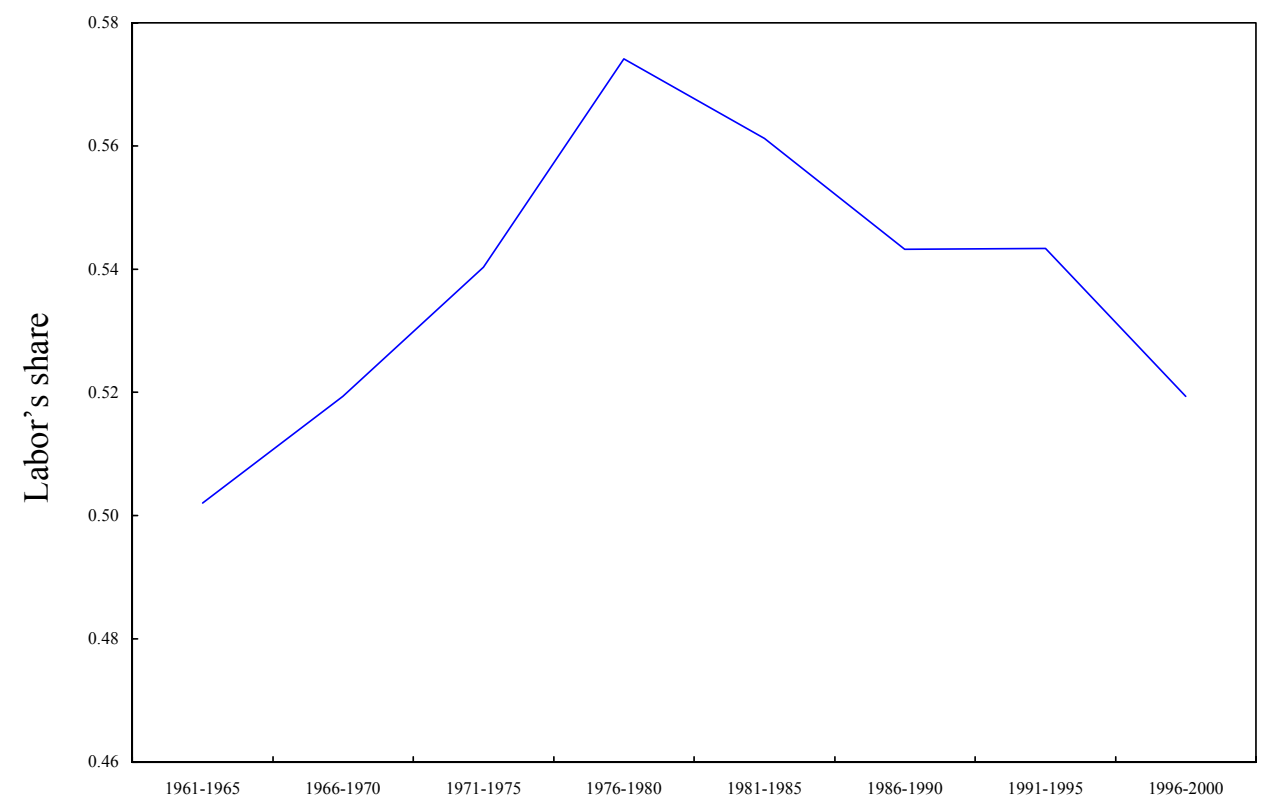

Source: OECD, Structural Analysis Database.

Throughout the discussion of the effects of technological progress and globalization on labor's share in national income, one should keep in mind that both are positive phenomena, as documented in a vast theoretical and empirical literature. ${ }^{2}$ Technological progress directly raises per capita income and, hence, benefits everyone in the economy. Similarly, as a country specializes in the production of goods and services in which it has a comparative advantage, productivity growth increases, and living standards rise. Global competition keeps inflation in check, and free capital flows keep interest rates low. An open economy spurs innovation. Globalization allows for a more efficient allocation of resources worldwide and, thus, increases the size of the national income "pie." This paper examines a more limited question: How is the bigger pie distributed between capital and labor?

\footnotetext{
${ }^{2}$ See, for example, J. Bhagwati (2004), Deardorff (2003), and Aisbett (2005).
} 
There are several ways in which technological progress and globalization may have contributed to the decline in labor's share of national income. If a technology is laboraugmenting (as may have been true in the 1960s and 1970s), then the boost in the effectiveness of labor inputs raises real wages and, hence, the share of national income going to labor. ${ }^{3}$ Conversely, capital-augmenting technological progress - which may be the nature of the information technology (IT) revolution - will boost capital's returns and share. ${ }^{4}$ Since the IT revolution was accompanied by a fast fall in the prices of computer equipment, it led to a huge increase in the stock of computing capital in the economy that may have boosted the share of national income going to capital.

Turning to globalization, the process leads to increased trade flows and specialization between countries. According to the Heckscher-Ohlin model, trade allows countries to specialize in areas of comparative advantage and tends to equalize factor returns across countries. Accordingly, with increasing openness, capital-rich (industrial) countries would specialize in the production of capital-intensive goods. Returns to labor, the relatively scarce factor, would gradually decline, and labor's share in national income would fall as specialization progressed. The Heckscher-Ohlin model assumes that capital and labor are immobile and that trade acts as a substitute for factor mobility. Greater factor mobility that also characterizes globalization would only make the effect stronger. Thus, nontrade aspects of globalization should amplify the negative effect of trade openness on the labor share in industrial countries. In addition, by making capital more mobile, globalization may have decreased the bargaining power of the less mobile factor-labor. Unionization and employment-protection policies still push income toward labor, but their effect may have been weakened. Finally, globalization pressures might have pushed industrial countries to adopt labor-saving technologies, further squeezing labor's share.

The regression results in this paper strongly suggest that technological progress has been capital-augmenting during the globalization era. Although, before the mid-1980s, faster productivity growth was associated with higher labor income share, more recently productivity gains have tended to boost capital's share. Openness to trade and increasing trade with developing countries have had a negative effect on the labor share in the industrial countries, consistent with the prediction of the Heckscher-Ohlin theory. Although laborprotection policies still move income toward labor, globalization appears to have dampened this effect. The results suggest that the decline in labor's share in national income during the past few decades in the OECD member countries may have been largely an equilibrium, rather than a purely cyclical, phenomenon, as the distribution of national income between labor and capital adjusted to capital-augmenting technological progress and a more globalized world economy.

\footnotetext{
${ }^{3}$ This assumes that the absolute value of the elasticity of substitution between labor and capital is below one.

${ }^{4}$ See, for example, IMF (2002).
} 


\section{LiterATURE REVIEW}

The distribution of national income between capital and labor has always been of interest to economists and policymakers, since it measures how benefits from growth are shared across the factors of production. But, overall, there have been relatively few empirical studies that attempted to explain movements in the labor share and link them to a range of possible explanations.

Blanchard (1996) documented changes in the labor and capital shares of national income for a number of OECD member countries. He found that capital shares in continental European countries have been increasing since the early 1980s, while no significant changes occurred in Anglo-Saxon countries. Poterba (1997) focused on the behavior of factor shares in the United States, and concluded that there is a discernable downward trend, although not as pronounced as in Europe. Crotty and Epstein (1996) and Rodrik (1997) have argued that globalization has eroded labor's share, especially in Europe where it has declined significantly in past decades.

Findings by studies that link movements in labor's share and globalization reach broadly similar conclusions. Harrison (2002) analyzed the relationship between factor shares and standard measures of globalization, such as trade shares, exchange rate crises, movements in foreign investment, and capital controls. She found that changes in labor shares are driven by changes in factor endowments and government spending, as well as by traditional measures of globalization, such as trade shares, exchange rate crises, movements in foreign investment, and capital controls. She finds that capital controls are associated with an increase in labor's share and that increasing trade shares are associated with a fall in labor's share. Foreign investment flows are associated with a fall in labor's share. Harrison's dataset includes poor, middle-income, and rich countries. This paper focuses its analysis on industrial countries, because they have more macroeconomic stability and splits the sample in 1985 to account for structural change brought about by the IT revolution. It also takes a detailed look at the effect of technological change and employment protection in conjunction with standard measures of trade openness.

Ripatti and Vilmunen (2001) look at the reasons for the decline in labor's share in Finland. They assume that the aggregate production technology is given by the constant elasticity of substitution (CES) production function, ${ }^{5}$ and deduce that the effect of the capital-output ratio and capital-augmenting technological progress on factor shares depends on the nature of input substitutability. Building on this work, Appendix VI presents a simple model for the postglobalization/post-IT revolution era.

\footnotetext{
${ }^{5}$ The constant returns to scale Cobb-Douglas production function $Y=A K^{\alpha} L^{1-\alpha}$ cannot explain changes in labor and capital shares, since it based on the assumption of constant factor shares in the national income, equal to their respective output elasticities. Namely, capital's share is always equal to $\alpha$ while labor's share is equal to $(1-\alpha)$. This means that different types of technology shocks $A$ cannot affect the income shares going to capital and labor.
} 
Bentolila and Saint-Paul (2003) suggested that movements in labor's share can be decomposed into movements along a technology-determined SK (share-capital) schedule. They looked at panel data for 12 OECD member countries over the period 1972-92 and estimated the relationship between labor's share and capital-output ratio. They found a significant relationship between the two key variables, as well as evidence of movements in the labor share owing to either shifts in the SK schedule, arising from total factor productivity and changes in the price of oil, and movements off this schedule, arising from labor adjustment costs and the bargaining power of labor.

\section{EMPIRICAL STRATEGY}

The priors are tested on a panel of 18 industrial countries over the $1960-2000$ period. The data are averaged over successive five-year periods to eliminate cyclical effects. Since most studies identify a change in the nature of technological progress and a (possibly related) acceleration of the globalization process in the mid-1980s, the sample is split in 1985, with the earlier period designated the "preglobalization/pre-IT revolution" and later period the "postglobalization/post-IT revolution" (IMF, 2002).

The basic specification is a panel regression with country-fixed effects (a "level" specification). Time-fixed effects were also added, but the Hausman test indicated that these were not necessary. A measure of labor's share is then related on the levels of explanatory variables by equation:

$$
Y_{i t}=\beta_{0 i}+\beta_{1} X_{i t}+u_{i t,} i=1, \ldots, N, t=1, \ldots, T
$$

where $Y$ is a measure of labor's share, $X$ is a matrix of explanatory variables, $u_{i}$ is the error term, and the $\beta$ s represent estimated coefficients.

As a robustness check, the model is also estimated in first differences.

$$
\Delta Y_{i t}=\beta_{0}+\gamma_{t}+\beta_{1} \Delta X_{i t}+u_{i t}
$$

For these "delta" regressions, the fixed effects are dropped, since taking first differences of the observations would control for any country-specific effects. Time-fixed effects are included whenever the appropriate Hausman test indicated that they are significant.

This paper looks at three dependent variables:

- Compensation share in national income (CS) includes share of wages and salaries, employer-financed benefits, unemployment insurance, social security, and workmen's compensation in the national income.

- Employment share in national income $(E S)$ is a broader measure, which also includes self-employment income. Not all of self-employment income is included because some of this income represents a return on investment or economic profit. I follow a common convention since Johnson (1954) by allocating two-thirds to labor earnings, and one-third to capital income. 
- The Gini coefficient (Gini) is a standard measure of income inequality. Data on Gini coefficients came primarily from the Dollar-Kraay ${ }^{6}$ dataset and partially from WIID database. ${ }^{7}$ It is interesting to compare changes in the labor shares and the Gini coefficients across countries. In particular, labor shares appear to have varied less, but inequality appears to have changed more in the mostly English-speaking countries (Figures 2 and 3).

Figure 2. Gini Coefficient in Mostly English-Speaking and Other Countries

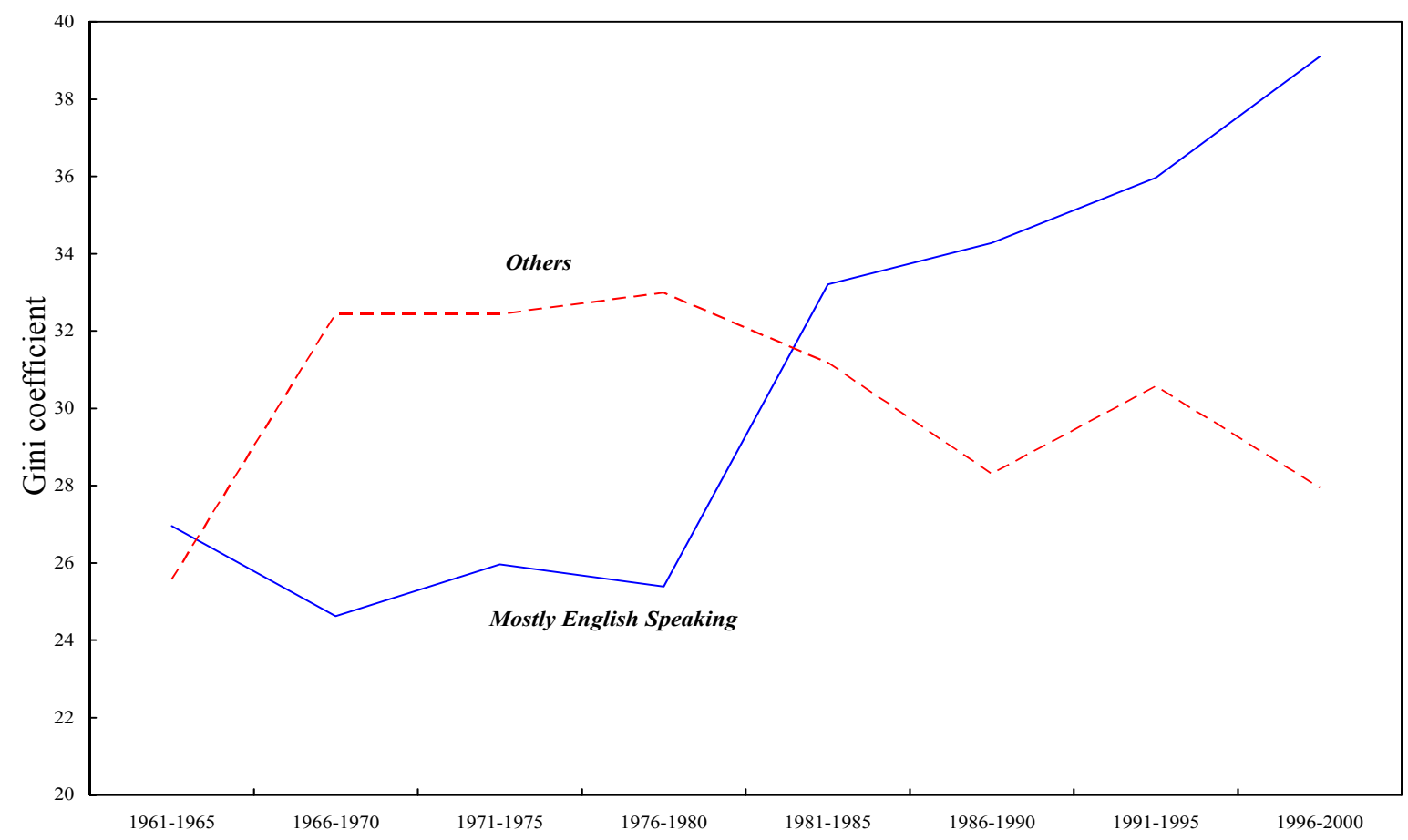

Sources: World Bank, World Income Inequality Database, Dollar and Kraay (2001) dataset.

Coverage: "Mostly English-speaking countries" includes Australia, the United Kingdom, the United States, Ireland, and Canada. Others includes Austria, Belgium, Denmark, Finland, and France.

\footnotetext{
${ }^{6}$ Data from David Dollar and Aart Kraay “Growth is Good for the Poor", The World Bank, March 2001.

${ }^{7}$ World Income Inequality Database (WIID), downloaded from the World Bank Website.
} 
Figure 3. Labor's Share in Mostly English-Speaking and Other Countries (Ratio of labor income to national income)

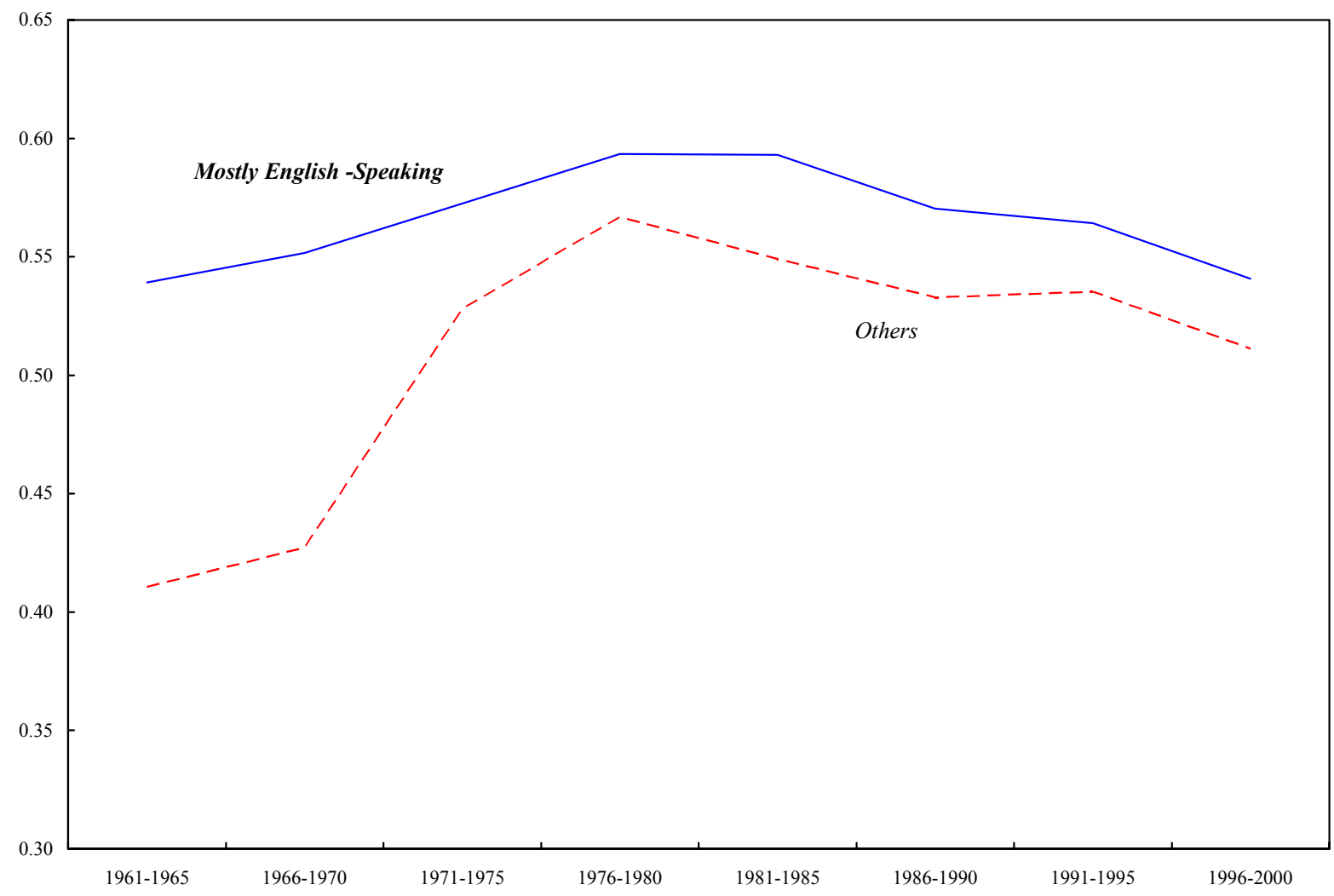

Source: OECD Analytical Database.

Coverage: "Mostly English-speaking countries" includes Australia, the United Kingdom, the United States, Ireland, and Canada. "Others” includes Austria, Belgium, Denmark, Finland, France.

The explanatory variables include a number of proxies for each concept.

Productivity and technology — the paper uses two proxies for productivity:

- Labor productivity of total economy (LProd) - measures the amount of real output accounted for by a unit of labor. It is defined as GDP per hour worked.

- $\quad$ Productivity per worker (ProdW) - measures the amount of real output accounted for by each worker. It is defined as GDP divided by total employment.

Since there might be a lag in the response of wages to productivity increases, the paper also experiments with lags of these two variables (LagLProd and LagProdW, respectively). If compensation and employment shares rise with labor productivity, we can deduce that technological change is labor-augmenting, but if the opposite is true, technological change is capital-augmenting. The prior is that while the nature of technological progress experienced prior to 1985 may have benefited labor, productivity increases after 1985 have been capitalaugmenting (See Appendix VI). 
If the nature of technological progress has been capital augmenting, the wealthy would tend to benefit more than the poor, and inequality should worsen. The IT revolution has probably favored the most highly skilled workers at the expense of those with the fewer skills. So technological progress may be characterized as biased in favor of those with skills. As a result, labor's share would drop, and the Gini coefficient would rise during the globalization/IT revolution era as income moves toward those with higher human capital.

Openness to trade - the paper uses four proxies for openness to trade:

- $\quad$ Ratio of trade to $G D P=($ Exports + Imports $) / G D P$.

(Open) is a standard and most frequently used proxy for a country's openness to trade.

- $\quad$ Trade share with developing countries $=($ Exports to developing countries + Imports from developing countries)/Total trade.

(TradeDev) captures the effect of trading with lower-cost countries.

- Foreign Direct Investment (FDI) to GDP ratio $=($ FDIinward $+F D I o u t w a r d) / G D P$. $(F D I)$ is a good proxy for capital mobility. Compensation and labor share should decrease as capital flows to lower-cost countries.

- $\quad$ Ratio of Capital flows to GDP = Capital Flows/GDP.

(KFlow) is used as an alternative measure of capital mobility.

The prior, based on the Heckscher-Ohlin effects, is that labor's share would decrease in all these variables and that globalization would likely strengthen these effects. According to the Heckscher-Ohlin model, industrial countries are abundant in high-skilled workers, while developing countries are abundant in low-skilled workers. Increasing openness to trade would cause the labor share to fall and inequality to rise. Higher capital mobility could make this effect stronger.

Bargaining Power of Labor - the paper uses two proxies for the bargaining power of labor:

- Union Density (UN). The percentage of unionized workforce. ${ }^{8}$

- Employment Protection (EP). This variable ranges from 0 to 2, increasing with strictness of employment protection.

Higher degree of unionization and employment protection should have a positive effect on wages, but negative effects on employment. The net effect of these variables on the labor share is expected to be positive, but possibly eroding with globalization. Rodrik (1997) looked at the bargaining game between capital and labor in which globalization increases capital mobility, thus increasing capital's bargaining power and its share of national income to the detriment of labor. Since lower-skilled workers benefit from employment protection

\footnotetext{
${ }^{8}$ Sincere thanks go to Xavier Debrun for sharing his dataset on these variables.
} 
more than high-skilled workers, one would expect income inequality to drop when measures of the bargaining power of labor increase.

\section{RESUlts}

\section{A. Preferred Specification}

A wide range of possible specifications were estimated, both bivariate and multivariate. Results of bivariate regressions are reported in Appendix II. The bivariate regressions suggested that the explanatory variables affected labor compensation with the expected sign, but multivariate results indicated that the variables representing similar concepts - for example, the two measures of productivity — were generally highly collinear (Appendix III reports the correlation matrix of explanatory variables).

As a result, in the multivariate specifications the compensation/employment share and the Gini coefficient were regressed only on one proxy for each of trade openness, productivity, and employment protection. In the preferred specification, the right-hand side variables include trade openness, lagged productivity per worker, and employment protection. ${ }^{9}$ The unemployment rate was included in the regressions to account for the dampening effect that employment protection policies might have on job creation. Regression results are reported in Table $1 .^{10}$

How well do the regression results conform to the priors on how the process of globalization should have affected the labor share through trade, nature of technology, and the bargaining power of labor?

During the preglobalization/pre-IT revolution era, technology appears to have been laboraugmenting, with labor's share increasing with faster productivity. The IT revolution, on the other hand, appears to have been capital-augmenting, lowering labor's share in countries whose productivity grew more rapidly. During the preglobalization period, a 1 percentage point increase in lagged productivity per worker increased compensation and employment share by 0.34 and 0.29 percentage point, respectively. Both level and delta regressions suggest that the results are robust and significant at the 99 percent confidence level. After 1985, however, increases in labor productivity went to raise the share of capital in national income. After the IT revolution, a 1 percentage point increase in lagged productivity

\footnotetext{
${ }^{9}$ The trade-to-GDP ratio is the most frequently used measure of openness. Since productivity increases might not affect compensation immediately, lagged productivity per worker was used. As a measure of labor's bargaining power, employment protection is preferred.

${ }^{10}$ Note that two-stage least-squares regression of compensation share on productivity per worker, with lagged productivity per worker being used as an instrument, produced results very similar to those obtained using an noninstrumented regression. Formal Hausman tests also indicate that endogeneity problems are not particularly serious for productivity variables.
} 


\begin{tabular}{|c|c|c|c|c|}
\hline \multirow[t]{2}{*}{ Compensation Share Regressions } & \multicolumn{2}{|c|}{ Pre-IT/Globalization Era } & \multicolumn{2}{|c|}{ IT/Globalization Era } \\
\hline & Level & Delta & Level & Delta \\
\hline \multirow[t]{2}{*}{ (Exports+Imports)/GDP } & -0.08 & -0.06 & $-0.14 * * *$ & $-0.15 * * *$ \\
\hline & $(0.08)$ & $(0.06)$ & $(0.02)$ & $(0.02)$ \\
\hline \multirow[t]{2}{*}{ Lagged productivity per worker } & $0.35 * * *$ & $0.52 * * *$ & $-0.24 * * *$ & -0.13 \\
\hline & $(0.02)$ & $(0.12)$ & $(0.06)$ & $(0.09)$ \\
\hline \multirow[t]{2}{*}{ Employment protection } & 0.01 & $0.03 * * *$ & 0.018 & 0.01 \\
\hline & $(0.01)$ & $(0.01)$ & $(0.017)$ & $(0.04)$ \\
\hline Country effects: & fixed & none & fixed & none \\
\hline Time (period) effects: & none & none & none & none \\
\hline $\mathrm{N}$ & 48 & 49 & 72 & 54 \\
\hline$R^{2}$ & 0.95 & 0.35 & 0.94 & 0.27 \\
\hline \multicolumn{5}{|l|}{ Employment Share Regressions } \\
\hline & Level & Delta & Level & Delta \\
\hline \multirow[t]{2}{*}{ (Exports+Imports)/GDP } & $-0.21 * * *$ & $-0.15 * * *$ & $-0.17 * * *$ & $-0.18 * * *$ \\
\hline & $(0.07)$ & $(0.05)$ & $(0.04)$ & $(0.05)$ \\
\hline \multirow[t]{2}{*}{ Lagged Productivity Per Worker } & $0.29 * * *$ & $0.38 * * *$ & $-0.11^{* *}$ & -0.03 \\
\hline & $(0.01)$ & $(0.10)$ & $(0.04)$ & $(0.10)$ \\
\hline \multirow[t]{2}{*}{ Employment Protection } & $0.05 * * *$ & $0.08 * * *$ & $0.10 * * *$ & 0.054 \\
\hline & $(0.00)$ & $(0.00)$ & $(0.03)$ & $(0.04)$ \\
\hline Country effects: & Fixed & none & fixed & none \\
\hline Time (period) effects: & None & none & none & none \\
\hline $\mathrm{N}$ & 31 & 29 & 68 & 51 \\
\hline$R^{2}$ & 0.98 & 0.28 & 0.81 & 0.20 \\
\hline \multicolumn{5}{|l|}{ Gini Coefficient Regressions } \\
\hline & Level & Delta & Level & Delta \\
\hline \multirow[t]{2}{*}{ (Exports+Imports)/GDP } & -0.01 & -0.18 & -0.01 & -0.02 \\
\hline & $(0.23)$ & $(0.18)$ & $(0.04)$ & $(0.04)$ \\
\hline \multirow[t]{2}{*}{ Lagged Productivity Per Worker } & 0.13 & -0.17 & $0.15^{* *}$ & $-0.33 *$ \\
\hline & $(0.12)$ & $(0.14)$ & $(0.06)$ & $(0.18)$ \\
\hline \multirow[t]{2}{*}{ Employment Protection } & $-0.09 * *$ & -0.08 & -0.01 & -0.01 \\
\hline & $(0.03)$ & $(0.08)$ & $(0.01)$ & $(0.03)$ \\
\hline Country effects: & Fixed & none & fixed & none \\
\hline Time (period) effects: & Fixed & none & none & none \\
\hline $\mathrm{N}$ & 45 & 43 & 70 & 51 \\
\hline$R^{2}$ & 0.82 & 0.15 & 0.75 & 0.08 \\
\hline \multicolumn{5}{|c|}{$\begin{array}{l}\text { Sources: OECD; IMF; United States Department of Commerce, Bureau of Economic Analysis; and IMF } \\
\text { staff estimates. }\end{array}$} \\
\hline \multicolumn{5}{|c|}{$\begin{array}{l}{ }^{1} \text { One, two, and three asterisks indicate that coefficient is significant at the } 10,5 \text {, and } 1 \text { percent levels, } \\
\text { respectively. Standard errors are in parentheses. }\end{array}$} \\
\hline
\end{tabular}


per worker resulted in a decline of compensation and employment share by 0.24 and 0.11 percentage point, respectively. These coefficients are statistically significant. In the later period, faster productivity growth has also been associated with widening income inequality.

The regression results suggest that both compensation and employment share decrease with trade openness, but the effect is not as significant during the preglobalization era for the compensation share. As expected, globalization augments the Heckscher-Ohlin effect on labor and capital income shares. For a percentage point increase in the trade-to-GDP ratio, the compensation and employment share fall by 0.14 and 0.17 percentage point, respectively. Robustness checks conducted by regressing the first difference of compensation and employment shares on the first difference of the explanatory variables suggest that this effect is robust and significant.

No impact from trade on inequality was found. This finding is consistent with earlier studies using a range of techniques that have also failed to find such a link. See Appendix V for detailed results.

Finally, a higher degree of employment protection benefits labor more than capital, resulting in higher compensation and labor share. Globalization might dampen this effect by decreasing the bargaining power of labor. During the preglobalization period, a point increase in the degree of employment protection raises compensation and employment share by 0.01 and 0.05 of a percentage point respectively. The effect is small, but robust and significant for employment share. During the globalization era, the effect of employment protection on compensation and labor share is still positive and significant, although not as robust. For a 1 percentage point increase in employment protection, compensation and employment share increase by 0.02 and 0.1 of a percentage point, respectively. Increases in the bargaining power of labor correspond with lower inequality as was expected, but the results are not significant for the postglobalization era.

\section{B. Robustness Checks}

The regression results are robust and broadly similar across various specifications.

Robustness checks included using alternative proxies for openness, productivity, and labor protection, dropping countries or years from the sample and including the inflation rate in the regressions (to account for the impact of nominal interest payments on nominal incomes). The results are broadly consistent with the priors and are reported in Appendix D.

\section{Technology/productivity}

The regression results are especially strong and robust for productivity. ${ }^{11}$ Productivity increases tended to boost labor share during the preglobalization/pre-IT era. Regression results suggest that for a percentage point increase in the labor productivity of the total economy (LProd), the compensation share in the national income increases by $0.22-$

\footnotetext{
${ }^{11}$ Some of the results for alternative specifications appear in Appendix IV. Results for other possible combination of explanatory variables are available from the author.
} 
0.44 percentage point, while the employment share increases by $0.11-0.48$ percentage point. The effect is even stronger for an increase in productivity per worker (ProdW). A percentage point increase in productivity per worker raises the compensation share by $0.25-$

0.58 percentage point and the employment share by $0.13-0.61$ percentage point. These effects are always significant, at the 99 percent confidence level. From this we can conclude that productivity increases prior to 1985 have been labor-augmenting. If technological progress is labor-augmenting during the preglobalization/pre-IT period, then inequality should decrease with increases in productivity. While most specifications produce the expected result (the Gini coefficient falls with productivity), the results are not always robust or significant.

The regression results are also very strong and robust for the postglobalization/post-IT revolution era. They suggest that for a percentage point increase in labor productivity of the total economy (LProd), the compensation share in national income falls by $0.13-$ 0.19 percentage point, while the employment share falls by $0.05-0.21$ percentage point. The effect is always significant, at the 99 percent confidence level. Changes in productivity per worker also have strong effects on the labor share. Every percentage point increase in productivity per worker (ProdW) decreases the compensation share by $0.25-0.36$ percentage point. The results are significant at the 99 percent confidence level and robust. From this we can conclude that productivity increases after 1985 have been capital-augmenting. The regression results are very similar when lags of productivity variables are used. If technological progress is capital augmenting during the postglobalization/post- IT revolution era, inequality should increase with increases in productivity. While most specifications produce the expected result, the results are not always significant, nor are they robust.

\section{Trade openness}

Consistent with the priors, regression results for trade openness show that globalization augments the Heckscher-Ohlin effect on labor and capital income shares. For every percentage point increase in openness (Open), the compensation share falls by $0.13-$ 0.15 percentage point, while the employment share falls by about 0.16 percentage point. The effect is significant at the 99 percent confidence level for all possible combinations of explanatory variables, and the results are robust. Employment is more responsive to openness than the compensation share, suggesting that self-employment income may also drop when openness increases.

Regressing labor's share on trade share with developing countries (TradeDev), productivity, and labor protection variables produce somewhat surprising results during the preglobalization/pre-IT era. It seems that for every percentage point increase in the trade share with developing countries, the compensation share rises by $0.15-0.18$ percentage point, while the employment share rises from by $0.23-0.26$ percentage point. The results are significant at the 99 percent and are robust. One possible explanation for this is that the Heckscher-Ohlin effect was not as strong prior to globalization. The implications of the Heckscher-Ohlin model might fail to hold when there are significant barriers to trade, high transportation costs and big differences in technologies between countries. While twenty years ago (prior to 1985), most countries in our study imposed significant controls on capital transactions, most of these restrictions disappeared during the globalization era (1985-2000). 
Because the Heckscher-Ohlin model is more appropriate for the postglobalization/post-IT era, its implications tend to hold better. There is generally a negative effect on compensation and employment of increasing trade share with developing countries.. Regarding inequality, the results are more strongly in favor of the Heckscher-Ohlin implications during the globalization era, since the Gini coefficient rises with the trade share with developing countries. This could be a reflection of rising incomes of high skilled workers and falling incomes of low-skilled workers. However, these results are not robust and are not always significant.

When the FDI-to-GDP ratio (FDI) is used as a proxy for openness and international capital mobility, results again differ in the two periods. Regressions for the preglobalization/pre-IT era suggest that every percentage point increase in this ratio would decrease the employment share in the national income by $0.46-0.50$ percentage point. Results for the postglobalization/post-IT era suggest that as the FDI/GDP ratio rises by a percentage point, employment share falls by $0.10-0.15$ percentage point. The results are significant at the 99 percent confidence level. Globalization seems to heighten the effect that the FDI/GDP ratio has on inequality. While higher capital mobility tends to raise the average standard of living, it tends to benefit the high-skilled more than the low-skilled. Multivariate regression results for the postglobalization/post-IT era indeed suggest that inequality increases when the FDI/GDP ratio rises. The results show the Gini coefficient rising by about 0.07 percentage point for every percentage point increase in the FDI/GDP ratio.

Regressions of the labor share on the ratio of capital flows to GDP (Kflow) produce results very similar to those for regressions with the variables Open and FDI .

\section{Bargaining power of labor}

For the preglobalization era, the regression results suggest that both the compensation and the employment share indeed increase with employment protection $(E P)$, and the effect is significant most of the time. For a 1 percentage point increase in the employment protection index, the compensation share increases by $0.02-0.04$ percentage point, while the employment share increases by $0.03-0.06$ percentage point. The results are robust. The effect of union density $(U N)$ on compensation and employment share is insignificant. Inequality decreases with the increase in the bargaining power of labor as was expected, but the results are not always robust or significant.

For the IT/globalization era, the regression results suggest that the employment share indeed increases with employment protection $(E P)$ by about $0.08-0.10$ percentage point. While this does not suggest that globalization dampened the effects of employment protection, the effect is not always significant. Prior to globalization the effect was almost always significant. Inequality decreases with the increase in the bargaining power of labor as was expected, but the results are not always robust or significant.

\section{Are the Results a Strictly European Phenomenon?}

One possible concern is that our sample includes mostly European countries. To check whether the results are being driven solely by trends in Europe, the regressions have been 
performed on a sample including six countries considered for the purposes of this study, as being outside continental Europe: Australia, Canada, Japan, the United States, the United Kingdom, and Norway. While the results are not as strong or significant when the sample includes only 6 out of 18 countries, they remain broadly similar. In particular, openness to trade decreases the labor share. A percentage point increase in productivity per worker raises labor share by 0.35 percentage point prior to the IT revolution, and the result is significant at the 95 percent confidence level. Labor's share declines with increases in productivity during the IT/globalization era, but the results are not always significant.

The results also suggest that prior to globalization trade was associated with lower inequality (negative coefficient). One plausible explanation is that Heckscher-Ohlin model was less appropriate because of significant trade barriers, high transportation costs, and large technology differences between industrial and developing countries. The effect of FDI on inequality prior to globalization is mostly positive, suggesting that while capital owners might benefit from increasing capital mobility, low-skilled workers would lose as their see their jobs moving overseas. However, the results are for the most part insignificant and are not robust. During the globalization era, increases in FDI would lead to increases in the inequality, while increases in labor productivity and labor protection polices have a negative effect.

\section{Conclusions}

This paper has examined impact of technology, openness, and employment protection policies on the labor share in national income in 18 OECD member countries during the period 1960-2000. The results strongly suggest that technological progress has been capitalaugmenting during the globalization era. Although before the mid-1980s productivity growth increased labor's share, since 1985 productivity gains have tended to boost profits. Openness to trade and the increasing trade with developing countries had a negative effect on the labor share in industrial countries, consistent with the prediction of the Heckscher-Ohlin model. Although labor-protection policies still move income toward labor, globalization seems to have made this effect less significant. Changes in labor's share during the preglobalization era are mostly driven by productivity increases and, to a lesser extent, by trade. During the postglobalization era, changes in labor's share of the national income have been equally driven by productivity and openness to trade.

The results on inequality are not as strong, but they do seem to suggest that the IT revolution has probably favored the most highly skilled workers at the expense of those with fewer skills. Thus, technological progress could be characterized as biased in favor of those with higher-level skills. Increasing openness to trade is associated with higher income inequality as industrial countries specialize in the production of skill-intensive goods. Employmentprotection policies lower inequality.

The results suggest that the decline in labor's share in the OECD member countries during the past few decades may have been an equilibrium, rather than a purely cyclical, phenomenon, as the distribution of national income between labor and capital adjusted to capital-augmenting technological progress and a more globalized world economy. One should, however, keep in mind that while labor's share of national income, predominantly 
from wages and salaries, has been declining, the effect on workers' wealth might have been smaller owing to the increasing direct and indirect ownership of equities by households.

This paper has looked at how globalization has affected the OECD countries in general. There are, however, some interesting cross-country variations that remain to be explained. It would also be interesting to expand the analysis to developing countries and see how globalization has affected their factor shares, although data limitations might make analysis of longer-term trends problematic. 


\section{Appendix I. Compensation Share}

Figure A1.1 Compensation Share: Actual and Fitted Values

(Ratio of employee compensation to national income)
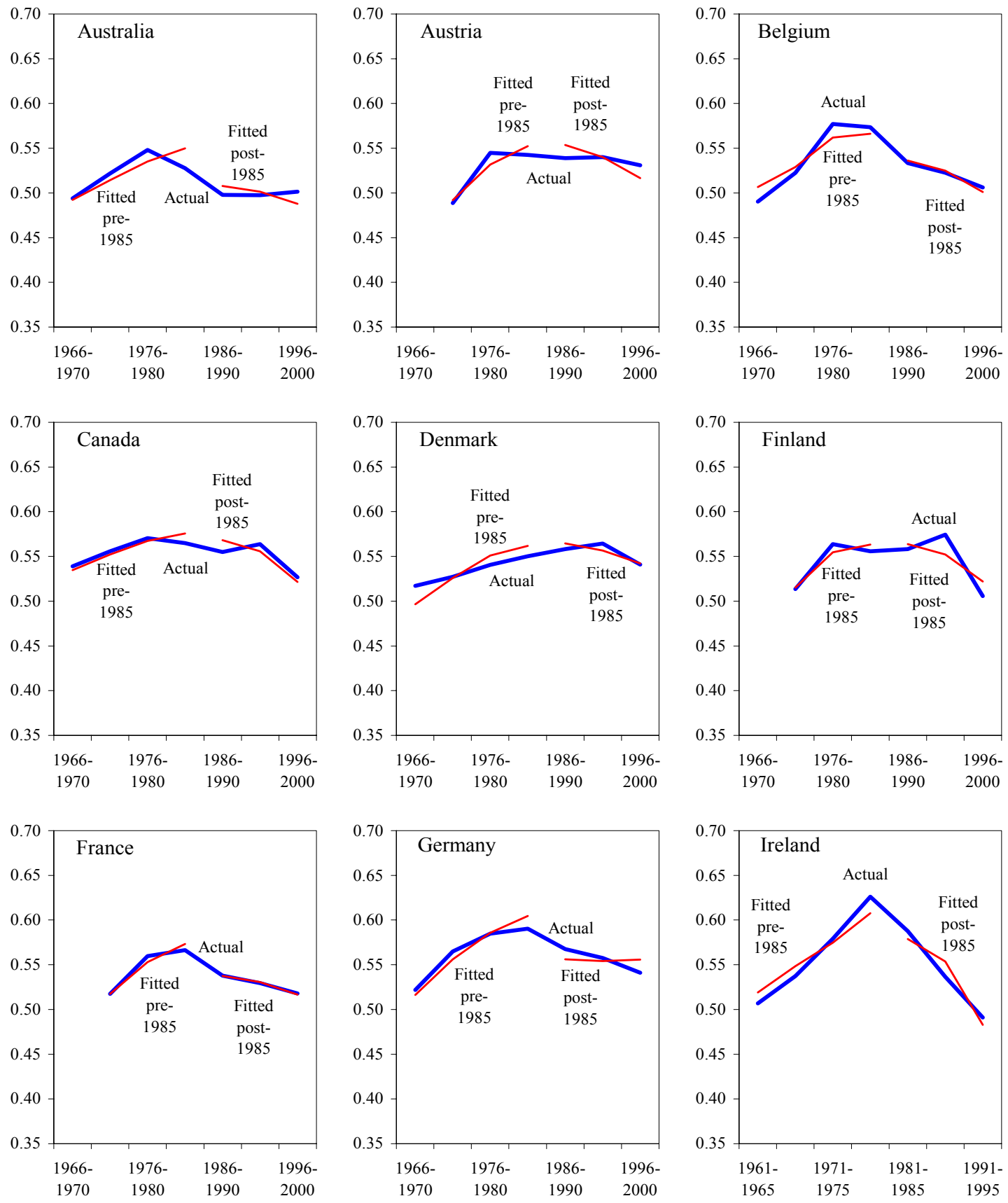

Sources: OECD Structural Analysis Database and IMF staff calculations 
Figure A1.1 Compensation Share: Actual and Fitted Values (concluded) (Ratio of employee compensation to national income)
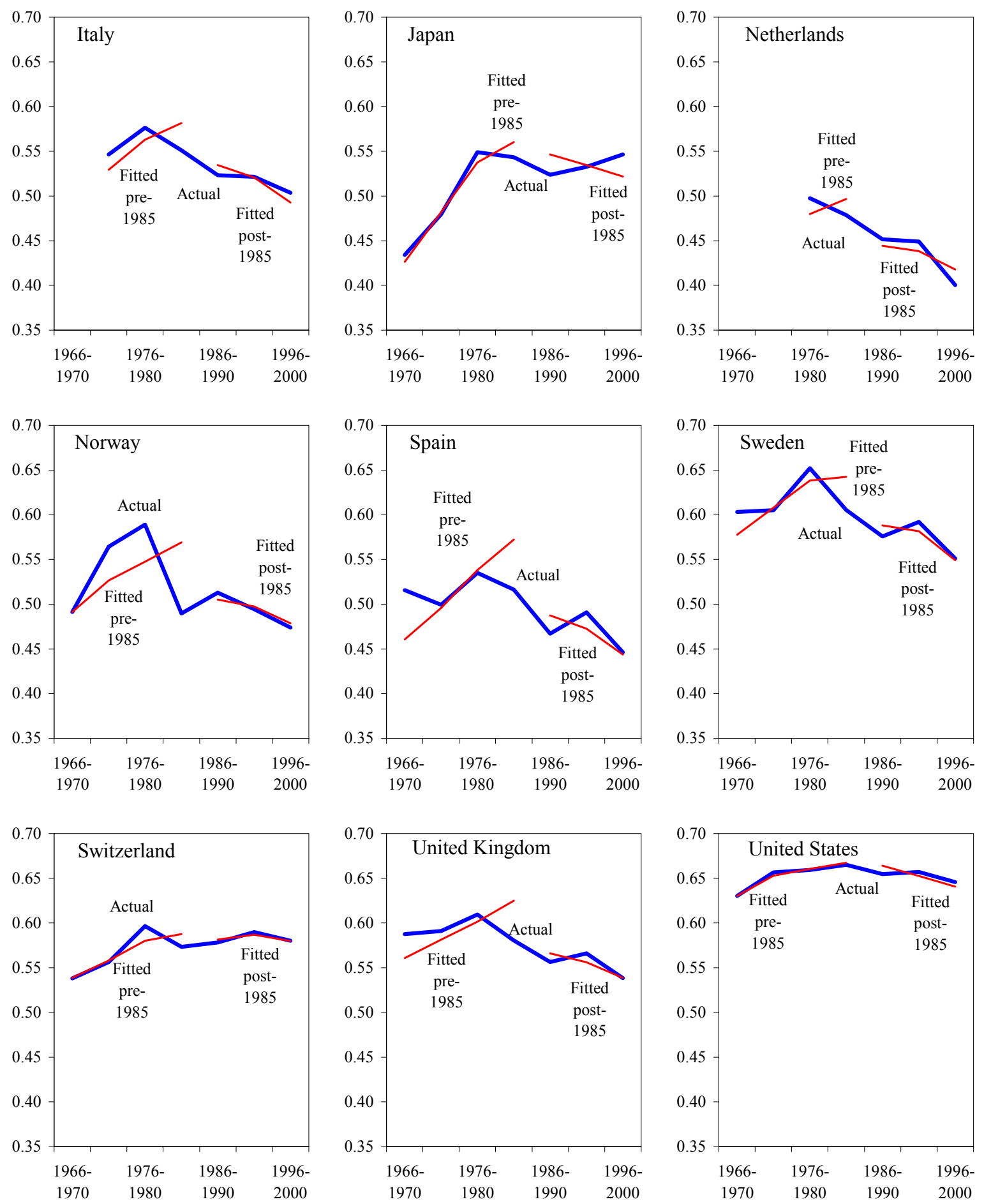

Sources: OECD Structural Analysis Database and IMF staff calculations. 


\section{Appendix II. A First Pass at Data: Bivariate Regression Results}

\begin{tabular}{|c|c|c|c|c|}
\hline \multicolumn{5}{|c|}{ Table A2.1 Results of Bivariate Regression: Compensation Share: } \\
\hline & \multicolumn{2}{|c|}{ Pre-IT/Globalization Era } & \multirow{2}{*}{\multicolumn{2}{|c|}{ Post-IT/Globalization Era }} \\
\hline & Toxol & Delta & & Dolta \\
\hline \multicolumn{5}{|l|}{ Openness } \\
\hline (Exports+Imports)/GDP & $\begin{array}{l}0.332 * * * \\
(0.055)\end{array}$ & $\begin{array}{l}0.012 \\
(0.061)\end{array}$ & $\begin{array}{l}-0.183 * * * \\
(0.011)\end{array}$ & $\begin{array}{l}-0.116 \\
(0.049)\end{array}$ \\
\hline Trade w/ Developing Countries & $\begin{array}{l}0.105^{* *} \\
(0.057)\end{array}$ & $\begin{array}{l}0.107 \\
(0.068)\end{array}$ & $\begin{array}{l}0.030 \\
(0.048)\end{array}$ & $\begin{array}{l}0.015 \\
(0.089)\end{array}$ \\
\hline FDI/GDP & $\begin{array}{l}-0.171^{* *} \\
(0.00) \\
\end{array}$ & $\begin{array}{l}0.023 \\
(0.086)\end{array}$ & $\begin{array}{l}-0.089 * * * \\
(0.016)\end{array}$ & $\begin{array}{l}-0.024 \\
(0.032)\end{array}$ \\
\hline \multicolumn{5}{|l|}{ Productivity } \\
\hline Labor Productivity & $\begin{array}{l}0.264 * * * \\
(0.034)\end{array}$ & $\begin{array}{l}0.111 * * * \\
(0.032)\end{array}$ & $\begin{array}{l}-0.186^{* * *} \\
(0.15)\end{array}$ & $\begin{array}{l}-0.295^{* * *} \\
(0.093)\end{array}$ \\
\hline Labor Productivity per Worker & $\begin{array}{l}0.329 * * * \\
(0.051)\end{array}$ & $\begin{array}{l}0.125^{* *} \\
(0.057)\end{array}$ & $\begin{array}{l}-0.324 * * * \\
(0.019)\end{array}$ & $\begin{array}{l}-0.485 * * * \\
(0.121)\end{array}$ \\
\hline Lagged Labor Productivity & $\begin{array}{l}0.280 * * * \\
(0.023)\end{array}$ & $\begin{array}{l}0.003 \\
(0.021)\end{array}$ & $\begin{array}{l}-0.183 * * * \\
(0.031)\end{array}$ & $\begin{array}{l}0.011 * * * \\
(0.003)\end{array}$ \\
\hline $\begin{array}{l}\text { Lagged Productivity Per } \\
\text { Worker }\end{array}$ & $\begin{array}{l}0.347^{* * *} \\
(0.024)\end{array}$ & $\begin{array}{l}0.525^{* * *} \\
(0.123)\end{array}$ & $\begin{array}{l}-0.298^{* * * *} \\
(0.028)\end{array}$ & $\begin{array}{l}-0.230^{* * *} \\
(0.048)\end{array}$ \\
\hline \multicolumn{5}{|l|}{ Bargaining Power } \\
\hline Employment Protection & $\begin{array}{l}0.006 \\
(0.004)\end{array}$ & $\begin{array}{l}0.014 * * \\
(0.005)\end{array}$ & $\begin{array}{l}0.012 \\
(0.012)\end{array}$ & $\begin{array}{l}0.015 \\
(0.054)\end{array}$ \\
\hline Union Density & $\begin{array}{l}-0.056 \\
(0.042)\end{array}$ & $\begin{array}{l}-0.104 * * * \\
(0.025)\end{array}$ & $\begin{array}{l}-0.008 \\
(0.067)\end{array}$ & $\begin{array}{l}0.077 \\
(0.056)\end{array}$ \\
\hline
\end{tabular}




\begin{tabular}{|c|c|c|c|c|}
\hline \multicolumn{5}{|c|}{ Table A2.2 Results of Bivariate Regressions: Employment Share } \\
\hline & \multicolumn{2}{|c|}{ Pre-IT/Globalization Era } & \multicolumn{2}{|c|}{ Post-IT/Globalization Era } \\
\hline & Level & Delta & Level & Delta \\
\hline \multicolumn{5}{|l|}{ Openness } \\
\hline (Exports+Imports)/GDP & $\begin{array}{l}0.186^{* * *} \\
(0.034)\end{array}$ & $\begin{array}{l}-0.032^{* *} \\
(0.013)\end{array}$ & $\begin{array}{l}-0.159^{*} \\
(0.019)\end{array}$ & $\begin{array}{l}-0.101 * * \\
(0.047)\end{array}$ \\
\hline Trade w/ Developing Countries & $\begin{array}{l}0.325 * * * \\
(0.047)\end{array}$ & $\begin{array}{c}0.141 \\
(0.112)\end{array}$ & $\begin{array}{l}-0.059 \\
(0.044)\end{array}$ & $\begin{array}{c}0.023 \\
(0.044)\end{array}$ \\
\hline FDI/GDP & $\begin{array}{c}0.010 \\
(0.037) \\
\end{array}$ & $\begin{array}{l}-0.471 * * * \\
(0.085)\end{array}$ & $\begin{array}{l}-0.156^{* * *} \\
(0.024)\end{array}$ & $\begin{array}{l}-0.180 \\
(0.080) \\
\end{array}$ \\
\hline \multicolumn{5}{|l|}{ Productivity } \\
\hline Labor Productivity & $\begin{array}{l}0.215^{* * *} \\
(0.052)\end{array}$ & $\begin{array}{c}0.007 \\
(0.143)\end{array}$ & $\begin{array}{l}-0.212^{* *} \\
(0.086)\end{array}$ & $\begin{array}{l}-0.151 \\
(0.110) \\
\end{array}$ \\
\hline Labor Productivity per Worker & $\begin{array}{l}0.263^{* * *} \\
(0.076)\end{array}$ & $\begin{array}{c}0.067 \\
(0.139)\end{array}$ & $\begin{array}{l}-0.365^{* *} \\
(0.142)\end{array}$ & $\begin{array}{l}-0.349^{* *} \\
(0.172)\end{array}$ \\
\hline Lagged Labor Productivity & $\begin{array}{l}0.219^{* * *} \\
(0.026)\end{array}$ & $\begin{array}{l}-0.001 \\
(0.020)\end{array}$ & $\begin{array}{l}-0.116^{* * *} \\
(0.03)\end{array}$ & $\begin{array}{l}0.022 * * * \\
(0.007)\end{array}$ \\
\hline Lagged Productivity Per Worker & $\begin{array}{l}0.260^{* * *} \\
(0.029)\end{array}$ & $\begin{array}{l}0.393 * * * \\
(0.069) \\
\end{array}$ & $\begin{array}{l}-0.218^{* * *} \\
(0.059)\end{array}$ & $\begin{array}{l}-0.161 \\
(0.131) \\
\end{array}$ \\
\hline \multicolumn{5}{|l|}{ Bargaining Power } \\
\hline Employment Protection & $\begin{array}{l}0.044^{* * * *} \\
(0.002)\end{array}$ & $\begin{array}{l}0.057^{* * * *} \\
(0.009)\end{array}$ & $\begin{array}{l}0.106^{* * *} \\
(0.020)\end{array}$ & $\begin{array}{c}0.041 \\
(0.297)\end{array}$ \\
\hline Union Density & $\begin{array}{c}0.079 \\
(0.025) \\
\end{array}$ & $\begin{array}{l}-0.099 * * \\
(0.045)\end{array}$ & $\begin{array}{l}-0.193 * * * \\
(0.051)\end{array}$ & $\begin{array}{l}-0.048 \\
(0.367)\end{array}$ \\
\hline
\end{tabular}




\section{Appendix III. Correlation Matrix of Explanatory Variables}

\begin{tabular}{|l|r|r|r|r|r|r|r|r|r|}
\hline Table A3.1 Correlation Matrix of Explanatory Variables & & & & & \\
\hline & & & & & & & & \\
\hline & Open & TradeDev & FDI & LProd & ProdW & LagLProd & LagProdW & EP & UN \\
\hline Open & 1.000 & -0.668 & 0.312 & 0.026 & -0.041 & 0.003 & -0.040 & 0.064 & 0.344 \\
\hline TradeDev & -0.668 & 1.000 & -0.268 & -0.014 & 0.199 & -0.031 & 0.157 & 0.082 & -0.374 \\
\hline FDI & 0.312 & -0.268 & 1.000 & 0.406 & 0.225 & 0.405 & 0.266 & -0.344 & -0.042 \\
\hline LProd & 0.026 & -0.014 & 0.406 & 1.000 & 0.715 & 0.979 & 0.759 & -0.003 & -0.269 \\
\hline ProdW & -0.041 & 0.199 & 0.225 & 0.715 & 1.000 & 0.710 & 0.984 & -0.082 & -0.173 \\
\hline LagLProd & 0.003 & -0.031 & 0.405 & 0.979 & 0.710 & 1.000 & 0.782 & -0.065 & -0.262 \\
\hline LagProdW & -0.040 & 0.157 & 0.266 & 0.759 & 0.984 & 0.782 & 1.000 & -0.119 & -0.171 \\
\hline EP & 0.064 & 0.082 & -0.344 & -0.003 & -0.082 & -0.065 & -0.119 & 1.000 & 0.026 \\
\hline UN & 0.344 & -0.374 & -0.042 & -0.269 & -0.173 & -0.262 & -0.171 & 0.026 & 1.000 \\
\hline
\end{tabular}




\section{Appendix IV. Multivariate Regression Results for Alternative Specifications}

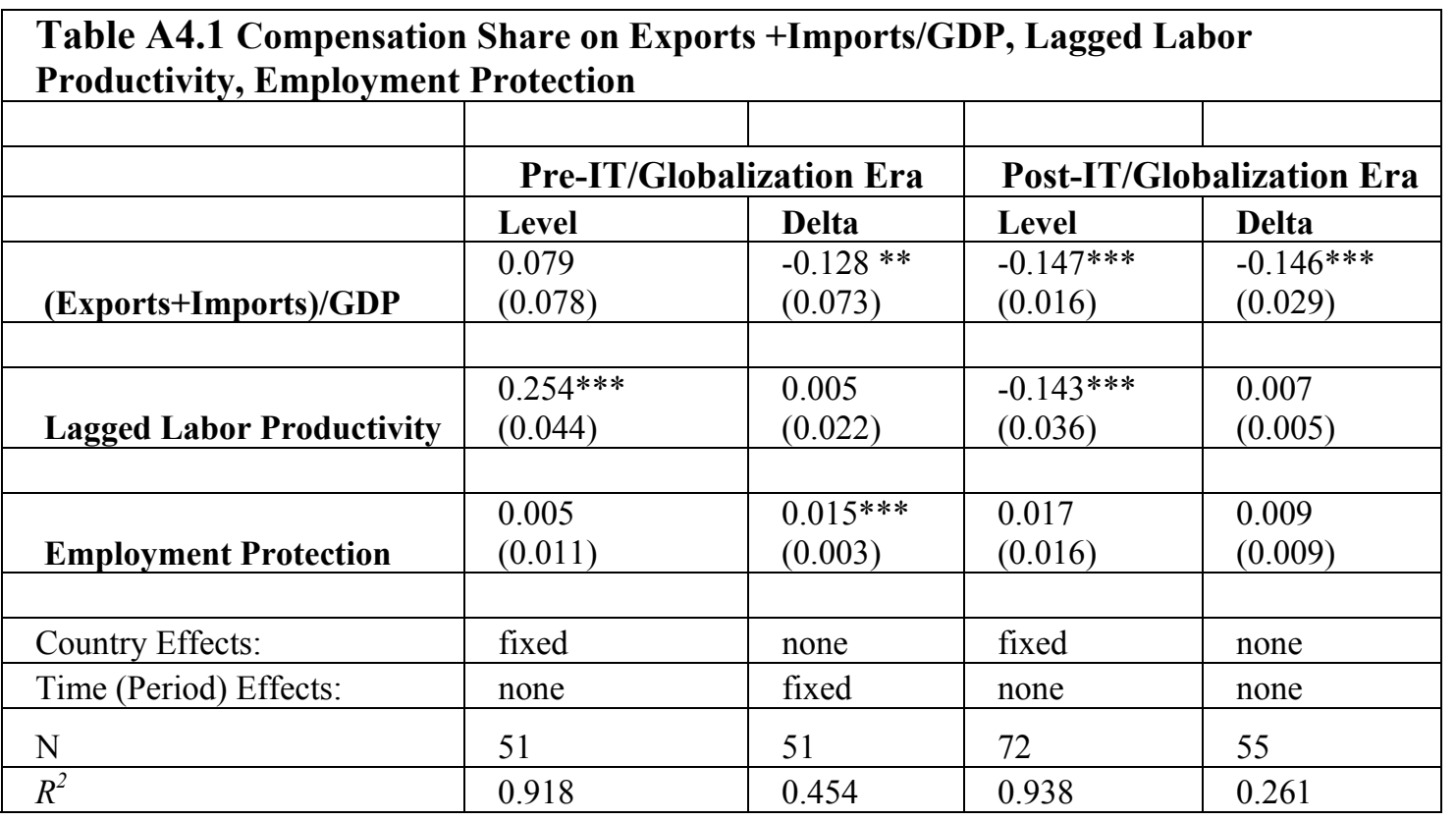

\begin{tabular}{|c|c|c|c|c|}
\hline \multicolumn{5}{|c|}{$\begin{array}{l}\text { Table A4.2 Employment Share: Exports +Imports/GDP, Lagged Labor Productivity, } \\
\text { Employment Protection }\end{array}$} \\
\hline & \multirow{2}{*}{\multicolumn{2}{|c|}{ Pre-IT/Globalization Era }} & \multirow{2}{*}{\multicolumn{2}{|c|}{ Post-IT/Globalization Era }} \\
\hline & & & & \\
\hline & Level & Delta & Level & Delta \\
\hline (Exports+Imports)/GDP & $\begin{array}{l}-0.180 * * \\
(0.078)\end{array}$ & $\begin{array}{l}-0.128 * * \\
(0.052)\end{array}$ & $\begin{array}{l}-0.166 * * * \\
(0.040)\end{array}$ & $\begin{array}{l}-0.185 * * * \\
(0.045)\end{array}$ \\
\hline Lagged Labor Productivity & $\begin{array}{l}0.233 * * * \\
(0.013) \\
\end{array}$ & $\begin{array}{l}0.038^{*} \\
(0.019)\end{array}$ & $\begin{array}{l}-0.066 * * * \\
(0.025)\end{array}$ & $\begin{array}{ll}0.011^{*} \\
(0.006)\end{array}$ \\
\hline Employment Protection & $\begin{array}{l}0.045^{* * *} \\
(0.001)\end{array}$ & $\begin{array}{l}0.089 * * * \\
(0.024)\end{array}$ & $\begin{array}{l}0.099 * * * \\
(0.025)\end{array}$ & $\begin{array}{l}0.052 \\
(0.042)\end{array}$ \\
\hline Country Effects: & fixed & none & fixed & none \\
\hline Time (Period) Effects: & none & none & none & none \\
\hline $\mathrm{N}$ & 31 & 29 & 68 & 51 \\
\hline$R^{2}$ & 0.974 & 0.195 & 0.807 & 0.203 \\
\hline
\end{tabular}




\begin{tabular}{|c|c|c|c|c|}
\hline \multicolumn{5}{|c|}{$\begin{array}{l}\text { Table A4.3 Compensation Share: Trade Shares w/Dev. Countries, Labor } \\
\text { Productivity, Employment Protection }\end{array}$} \\
\hline & \multicolumn{2}{|c|}{ Pre-IT/Globalization Era } & \multicolumn{2}{|c|}{ Post-IT/Globalization Era } \\
\hline & Level & Delta & Level & Delta \\
\hline $\begin{array}{l}\text { Trade Share w/ Dev. } \\
\text { Countries }\end{array}$ & $\begin{array}{l}0.176^{* * *} \\
(0.033) \\
\end{array}$ & $\begin{array}{l}0.141 * * \\
(0.060) \\
\end{array}$ & $\begin{array}{l}0.024 \\
(0.071)\end{array}$ & $\begin{array}{l}0.015 \\
(0.069) \\
\end{array}$ \\
\hline Labor Productivity & $\begin{array}{l}0.221 * * * \\
(0.033)\end{array}$ & $\begin{array}{l}0.121^{* *} \\
(0.056) \\
\end{array}$ & $\begin{array}{l}-0.189 * * * \\
(0.009)\end{array}$ & $\begin{array}{l}-0.373^{* * *} \\
(0.047) \\
\end{array}$ \\
\hline Employment Protection & $\begin{array}{l}0.016^{* * *} \\
(0.004)\end{array}$ & $\begin{array}{l}0.023 * * * \\
(0.006) \\
\end{array}$ & $\begin{array}{l}0.011 \\
(0.013)\end{array}$ & $\begin{array}{l}0.010 \\
(0.031)\end{array}$ \\
\hline Country Effects: & fixed & none & fixed & none \\
\hline Time (Period) Effects: & none & fixed & none & none \\
\hline $\mathrm{N}$ & 66 & 67 & 72 & 54 \\
\hline$R^{2}$ & 0.925 & 0.472 & 0.920 & 0.272 \\
\hline
\end{tabular}

\begin{tabular}{|c|c|c|c|c|}
\hline \multicolumn{5}{|c|}{$\begin{array}{l}\text { Table A4.4 Employment Share: Trade } \\
\text { Productivity, Employment Protection }\end{array}$} \\
\hline & \multirow{2}{*}{\multicolumn{2}{|c|}{ Pre-IT/Globalization Era }} & \multirow{2}{*}{\multicolumn{2}{|c|}{ Post-IT/Globalization Era }} \\
\hline & & & & \\
\hline & Level & Delta & Level & Delta \\
\hline $\begin{array}{l}\text { Trade Share w/ Dev. } \\
\text { Countries }\end{array}$ & $\begin{array}{l}0.234 * * * \\
(0.034) \\
\end{array}$ & $\begin{array}{l}0.355^{* * *} \\
(0.116) \\
\end{array}$ & $\begin{array}{l}-0.048 \\
(0.111)\end{array}$ & $\begin{array}{l}-0.016 \\
(0.026) \\
\end{array}$ \\
\hline Labor Productivity & $\begin{array}{l}0.115^{* * *} \\
(0.004) \\
\end{array}$ & $\begin{array}{l}0.118 \\
(0.296)\end{array}$ & $\begin{array}{l}-0.138 * * * \\
(0.019)\end{array}$ & $\begin{array}{l}-0.224 * * * \\
(0.083)\end{array}$ \\
\hline Employment Protection & $\begin{array}{l}0.031 * * * \\
(0.010) \\
\end{array}$ & $\begin{array}{l}0.066^{* * *} \\
(0.012) \\
\end{array}$ & $\begin{array}{l}0.090^{* * *} \\
(0.025) \\
\end{array}$ & $\begin{array}{l}0.069^{* *} \\
(0.027)\end{array}$ \\
\hline Country Effects: & fixed & none & fixed & none \\
\hline Time (Period) Effects: & none & none & none & fixed \\
\hline $\mathrm{N}$ & 33 & 30 & 68 & 51 \\
\hline$R^{2}$ & 0.966 & 0.257 & 0.784 & 0.323 \\
\hline
\end{tabular}




\begin{tabular}{|c|c|c|c|c|}
\hline & & & & \\
\hline & \multicolumn{2}{|c|}{ Pre-IT/Globalization Era } & \multicolumn{2}{|c|}{ IT/Globalization Era } \\
\hline & Level & Delta & Level & Delta \\
\hline (Exports+Imports)/GDP & $\begin{array}{l}-0.036 \\
(0.057) \\
\end{array}$ & $\begin{array}{l}-0.016 \\
(0.071)\end{array}$ & $\begin{array}{l}-0.132 * * * \\
(0.018)\end{array}$ & $\begin{array}{l}-0.123^{* * *} \\
(0.013)\end{array}$ \\
\hline Productivity per Worker & $\begin{array}{l}0.286^{* * * *} \\
(0.046) \\
\end{array}$ & $\begin{array}{l}0.133^{* *} \\
(0.059) \\
\end{array}$ & $\begin{array}{l}-0.252^{* * *} \\
(0.043)\end{array}$ & $\begin{array}{l}-0.415^{* * *} \\
(0.094)\end{array}$ \\
\hline Employment Protection & $\begin{array}{l}0.016^{* * *} \\
(0.006)\end{array}$ & $\begin{array}{l}0.016 * * * \\
(0.005)\end{array}$ & $\begin{array}{l}0.016 \\
(0.016) \\
\end{array}$ & $\begin{array}{l}0.013 \\
(0.033) \\
\end{array}$ \\
\hline Country Effects: & fixed & none & fixed & none \\
\hline Time (Period) Effects: & none & fixed & none & none \\
\hline $\mathrm{N}$ & 64 & 66 & 72 & 54 \\
\hline$R^{2}$ & 0.936 & 0.454 & 0.938 & 0.375 \\
\hline
\end{tabular}

\begin{tabular}{|c|c|c|c|c|}
\hline \multicolumn{5}{|c|}{$\begin{array}{l}\text { Table A4.6 Compensation Share: Trade Share s/Dev/ Countries, Productivity per } \\
\text { Worker, Employment Protection }\end{array}$} \\
\hline & \multicolumn{2}{|c|}{ Pre-IT/Globalization Era } & \multicolumn{2}{|c|}{ IT/Globalization Era } \\
\hline & Level & Delta & Level & Delta \\
\hline $\begin{array}{l}\text { Trade Share w/Dev. } \\
\text { Countries }\end{array}$ & $\begin{array}{l}0.183 * * * \\
(0.034)\end{array}$ & $\begin{array}{l}0.340 * * * \\
(0.087)\end{array}$ & $\begin{array}{l}0.013 \\
(0.071)\end{array}$ & $\begin{array}{l}-0.010 \\
(0.078)\end{array}$ \\
\hline Productivity per Worker & $\begin{array}{l}0.256^{* * *} \\
(0.041)\end{array}$ & $\begin{array}{l}0.274 * * \\
(0.116) \\
\end{array}$ & $\begin{array}{l}-0.348^{* * *} \\
(0.019)\end{array}$ & $\begin{array}{l}-0.539 * * * \\
(0.104)\end{array}$ \\
\hline Employment Protection & $\begin{array}{l}0.017 * * * \\
(0.003)\end{array}$ & $\begin{array}{l}0.038^{* * *} \\
(0.009)\end{array}$ & $\begin{array}{l}0.013 \\
(0.013)\end{array}$ & $\begin{array}{l}0.019 \\
(0.034)\end{array}$ \\
\hline Country Effects: & fixed & none & fixed & none \\
\hline Time (Period) Effects: & none & none & none & none \\
\hline $\mathrm{N}$ & 64 & 66 & 72 & 54 \\
\hline$R^{2}$ & 0.941 & 0.287 & 0.919 & 0.209 \\
\hline
\end{tabular}




\begin{tabular}{|c|c|c|c|c|}
\hline \multicolumn{5}{|c|}{$\begin{array}{l}\text { Table A4.7 Compensation Share: Exports+Imports/GDP, Lagged Labor Productivity, } \\
\text { Union Density }\end{array}$} \\
\hline & & & & \\
\hline & \multicolumn{2}{|c|}{ Pre-IT/Globalization Era } & \multicolumn{2}{|c|}{ IT/Globalization Era } \\
\hline & Level & Delta & Level & Delta \\
\hline (Exports+Imports)/GDP & $\begin{array}{l}0.107 * \\
(0.061)\end{array}$ & $\begin{array}{l}0.013 \\
(0.061)\end{array}$ & $\begin{array}{l}-0.149 * * * \\
(0.014)\end{array}$ & $\begin{array}{l}-0.151 * * * \\
(0.019)\end{array}$ \\
\hline Lagged Labor Productivity & $\begin{array}{l}0.261 * * * \\
(0.035) \\
\end{array}$ & $\begin{array}{l}-0.006 \\
(0.024) \\
\end{array}$ & $\begin{array}{l}-0.140 * * * \\
(0.030)\end{array}$ & $\begin{array}{l}-0.007 \\
(0.006)\end{array}$ \\
\hline Union Density & $\begin{array}{l}-0.121 \\
(0.083)\end{array}$ & $\begin{array}{l}-0.136^{* * *} \\
(0.009)\end{array}$ & $\begin{array}{l}0.043 \\
(0.039) \\
\end{array}$ & $\begin{array}{l}0.135 \\
(0.071) \\
\end{array}$ \\
\hline Country Effects: & fixed & none & fixed & none \\
\hline Time (Period) Effects: & none & fixed & none & none \\
\hline $\mathrm{N}$ & 51 & 66 & 72 & 54 \\
\hline$R^{2}$ & 0.920 & 0.471 & 0.937 & 0.291 \\
\hline
\end{tabular}

\begin{tabular}{|c|c|c|c|c|}
\hline \multicolumn{5}{|c|}{$\begin{array}{l}\text { Table A4.8 Compensation Share: Trade Share s/Dev/ Countries, Labor Productivity, } \\
\text { Union Density }\end{array}$} \\
\hline & & & & \\
\hline & \multicolumn{2}{|c|}{ Pre-IT/Globalization Era } & \multicolumn{2}{|c|}{ IT/Globalization Era } \\
\hline & Level & Delta & Level & Delta \\
\hline Trade Share w/ Dev. Countries & $\begin{array}{l}0.145^{* * *} \\
(0.034)\end{array}$ & $\begin{array}{l}0.090 \\
(0.076)\end{array}$ & $\begin{array}{l}0.023 \\
(0.070)\end{array}$ & $\begin{array}{l}0.006 \\
(0.068)\end{array}$ \\
\hline Labor Productivity & $\begin{array}{l}0.247 * * * \\
(0.034) \\
\end{array}$ & $\begin{array}{l}0.085 \\
(0.052) \\
\end{array}$ & $\begin{array}{l}-0.193 * * * \\
(0.026)\end{array}$ & $\begin{array}{l}-0.363 * * * \\
(0.066) \\
\end{array}$ \\
\hline Union Density & $\begin{array}{l}0.007 \\
(0.052)\end{array}$ & $\begin{array}{l}-0.081 * * \\
(0.035) \\
\end{array}$ & $\begin{array}{l}0.009 \\
(0.053)\end{array}$ & $\begin{array}{l}0.127 \\
(0.051)\end{array}$ \\
\hline Country Effects: & fixed & none & fixed & none \\
\hline Time (Period) Effects: & none & fixed & none & none \\
\hline $\mathrm{N}$ & 66 & 67 & 72 & 54 \\
\hline$R^{2}$ & 0.921 & 0.462 & 0.920 & 0.270 \\
\hline
\end{tabular}




\begin{tabular}{|c|c|c|c|c|}
\hline \multicolumn{5}{|c|}{$\begin{array}{l}\text { Table A4.9 Compensation Share: FDI/GDP Ratio, Labor Productivity, Employment } \\
\text { Protection }\end{array}$} \\
\hline & \multicolumn{2}{|c|}{ Pre-IT/Globalization Era } & \multicolumn{2}{|c|}{ IT/Globalization Era } \\
\hline & Level & Delta & Level & Delta \\
\hline FDI to GDP Ratio & $\begin{array}{l}0.141 * * * \\
(0.013)\end{array}$ & $\begin{array}{l}-0.01 \\
(0.086)\end{array}$ & $\begin{array}{l}-0.025 \\
(0.017)\end{array}$ & $\begin{array}{l}-0.011 \\
(0.022)\end{array}$ \\
\hline Labor Productivity & $\begin{array}{l}0.398^{* * *} \\
(0.027)\end{array}$ & $\begin{array}{l}0.177^{*} \\
(0.089)\end{array}$ & $\begin{array}{l}-0.170^{* * *} \\
(0.012)\end{array}$ & $\begin{array}{l}-0.369 * * * \\
(0.034)\end{array}$ \\
\hline Employment Protection & $\begin{array}{l}0.036^{* * *} \\
(0.002)\end{array}$ & $\begin{array}{l}0.026 * * * \\
(0.001)\end{array}$ & $\begin{array}{l}0.002 \\
(0.011)\end{array}$ & $\begin{array}{l}0.005 \\
(0.031)\end{array}$ \\
\hline Country Effects: & fixed & none & fixed & none \\
\hline Time (Period) Effects: & none & fixed & none & none \\
\hline $\mathrm{N}$ & 38 & 36 & 72 & 54 \\
\hline$R^{2}$ & 0.971 & 0.525 & 0.921 & 0.271 \\
\hline
\end{tabular}




\section{Appendix V. Inequality}

\begin{tabular}{|c|c|c|c|c|}
\hline \multicolumn{5}{|c|}{ Table A5.1 Gini Coefficient on Openness, Productivity, Bargaining Power } \\
\hline & \multicolumn{2}{|c|}{ Pre-IT/globalization Era } & \multicolumn{2}{|c|}{ IT/Globalization Era } \\
\hline & Level & Delta & Level & Delta \\
\hline \multicolumn{5}{|l|}{ Openness } \\
\hline (Exports+Imports)/GDP & $\begin{array}{l}-0.219 \\
(0.170)\end{array}$ & $\begin{array}{l}-0.242^{*} \\
(0.131)\end{array}$ & $\begin{array}{l}0.035 \\
(0.020)\end{array}$ & $\begin{array}{l}-0.076 \\
(0.062)\end{array}$ \\
\hline Trade w/ Developing & $\begin{array}{l}0.105 \\
(0.084) \\
\end{array}$ & $\begin{array}{l}-0.065 \\
(0.079) \\
\end{array}$ & $\begin{array}{l}0.089 \\
(0.095)\end{array}$ & $\begin{array}{l}0.038 \\
(0.114) \\
\end{array}$ \\
\hline FDI/GDP & $\begin{array}{l}0.091 \\
(0.057)\end{array}$ & $\begin{array}{l}-0.067 \\
(0.069)\end{array}$ & $\begin{array}{l}0.049 * * * \\
(0.038)\end{array}$ & $\begin{array}{l}-0.010 \\
(0.094)\end{array}$ \\
\hline \multicolumn{5}{|l|}{ Productivity } \\
\hline Labor Productivity & $\begin{array}{l}-0.211 * * * \\
(0.033)\end{array}$ & $\begin{array}{l}0.125 \\
(0.350)\end{array}$ & $\begin{array}{l}-0.012 * * \\
(0.057)\end{array}$ & $\begin{array}{l}-0.088 \\
(0.107)\end{array}$ \\
\hline Productivity per Worker & $\begin{array}{l}-0.208^{* * * *} \\
(0.043)\end{array}$ & $\begin{array}{c}0.039 \\
(0.251)\end{array}$ & $\begin{array}{l}0.068 * * * \\
(0.021)\end{array}$ & $\begin{array}{l}-0.119 \\
(0.153)\end{array}$ \\
\hline Lagged Labor Productivity & $\begin{array}{l}-0.165^{* * *} \\
(0.008)\end{array}$ & $\begin{array}{l}0.027 * * * \\
(0.010)\end{array}$ & $\begin{array}{l}0.035^{* * *} \\
(0.011)\end{array}$ & $\begin{array}{l}0.033 * * * \\
(0.011)\end{array}$ \\
\hline Lagged Productivity Per Worker & $\begin{array}{l}-0.094 * * * \\
(0.012)\end{array}$ & $\begin{array}{l}-0.178 \\
(0.171)\end{array}$ & $\begin{array}{l}0.052 * * * \\
(0.017)\end{array}$ & $\begin{array}{l}-0.264 \\
(0.183)\end{array}$ \\
\hline \multicolumn{5}{|l|}{ Bargaining Power } \\
\hline Employment Protection & $\begin{array}{l}-0.098^{* * * *} \\
(0.006)\end{array}$ & $\begin{array}{l}-0.083 \\
(0.007)\end{array}$ & $\begin{array}{l}-0.027 \\
(0.013)\end{array}$ & $\begin{array}{l}-0.006 \\
(0.026)\end{array}$ \\
\hline Union Density & $\begin{array}{l}-0.423 * * * \\
(0.149)\end{array}$ & $\begin{array}{l}-0.014 \\
(0.087)\end{array}$ & $\begin{array}{l}-0.330 \\
(0.104)\end{array}$ & $\begin{array}{l}-0.240 \\
(0.344)\end{array}$ \\
\hline
\end{tabular}




\section{Appendix VI. Multivariate regression results for alternative specifications}

\begin{tabular}{|c|c|c|c|c|}
\hline \multicolumn{5}{|c|}{$\begin{array}{l}\text { Table A6.1 Gini Coefficient on (Exports+Imports)/GDP, Lagged Labor Productivity, } \\
\text { Employment Protection }\end{array}$} \\
\hline & \multirow{2}{*}{\multicolumn{2}{|c|}{ Pre-IT/globalization Era }} & \multirow{2}{*}{\multicolumn{2}{|c|}{ IT/Globalization Era }} \\
\hline & & & & \\
\hline & Level & Delta & Level & Delta \\
\hline (Exports+Imports)/GDP & $\begin{array}{l}0.037 \\
(0.179)\end{array}$ & $\begin{array}{l}-0.175 \\
(0.171)\end{array}$ & $\begin{array}{l}-0.015 \\
(0.041)\end{array}$ & $\begin{array}{l}-0.028 \\
(0.050)\end{array}$ \\
\hline Lagged Labor Productivity & $\begin{array}{l}-0.124^{* * *} \\
(0.035)\end{array}$ & $\begin{array}{l}0.002 \\
(0.013)\end{array}$ & $\begin{array}{l}0.093^{* *} \\
(0.037)\end{array}$ & $\begin{array}{l}0.023 \\
(0.020)\end{array}$ \\
\hline Employment Protection & $\begin{array}{l}-0.108^{* * *} \\
(0.023)\end{array}$ & $\begin{array}{l}-0.085 \\
(0.074)\end{array}$ & $\begin{array}{l}-0.001 \\
(0.014)\end{array}$ & $\begin{array}{l}-0.013 \\
(0.026)\end{array}$ \\
\hline Country Effects: & fixed & none & fixed & none \\
\hline Time (Period) Effects: & none & none & none & none \\
\hline $\mathrm{N}$ & 47 & 45 & 70 & 51 \\
\hline$R^{2}$ & 0.792 & 0.139 & 0.751 & 0.064 \\
\hline
\end{tabular}

\begin{tabular}{|c|c|c|c|c|}
\hline \multicolumn{5}{|c|}{$\begin{array}{l}\text { Table A6.2 Gini Coefficient on Trade Share w/Dev. Countries, Lagged Labor } \\
\text { Productivity, Employment Protection }\end{array}$} \\
\hline & \multicolumn{2}{|c|}{ Pre-IT/globalization Era } & \multicolumn{2}{|c|}{ IT/Globalization Era } \\
\hline & Level & Delta & Level & Delta \\
\hline \multirow[t]{2}{*}{$\begin{array}{l}\text { Trade Share w/Developed } \\
\text { Countries }\end{array}$} & $-0.195^{* *}$ & $-0.158 * * *$ & 0.039 & 0.024 \\
\hline & $(0.094)$ & $(0.052)$ & $(0.087)$ & $(0.070)$ \\
\hline \multirow[t]{2}{*}{ Lagged Labor Productivity } & $-0.075 * * *$ & $0016^{* *}$ & $0.092 * * *$ & 0.023 \\
\hline & $(0.011)$ & $(0.007)$ & $(0.030)$ & $(0.018)$ \\
\hline \multirow[t]{2}{*}{ Employment Protection } & $-0.110 * * *$ & -0.096 & 0.001 & -0.009 \\
\hline & $(0.036)$ & $(0.074)$ & $(0.017)$ & $(0.040)$ \\
\hline Country Effects: & fixed & none & fixed & none \\
\hline Time (Period) Effects: & none & none & none & none \\
\hline $\mathrm{N}$ & 47 & 45 & 70 & 51 \\
\hline$R^{2}$ & 0.796 & 0.120 & 0.752 & 0.060 \\
\hline
\end{tabular}




\begin{tabular}{|c|c|c|c|c|}
\hline & & & & \\
\hline & \multicolumn{2}{|c|}{ Pre-IT/globalization Era } & \multicolumn{2}{|c|}{ IT/Globalization Era } \\
\hline & Level & Delta & Level & Delta \\
\hline \multirow[t]{2}{*}{ FDI/GDP Ratio } & $0.246^{* * *}$ & -0.026 & $0.073 * * *$ & 0.013 \\
\hline & $(0.0293)$ & $(0.015)$ & $(0.016)$ & $(0.076)$ \\
\hline \multirow[t]{2}{*}{ Lagged Labor Productivity } & $-0.209 * * *$ & $-0.003^{*}$ & 0.023 & 0.024 \\
\hline & $(0.007)$ & $(0.002)$ & $(0.033)$ & $(0.022)$ \\
\hline \multirow[t]{2}{*}{ Employment Protection } & $-0.193 * * *$ & $-0.177 * * *$ & $0.027 *$ & -0.008 \\
\hline & $(0.000)$ & $(0.056)$ & $(0.015)$ & $(0.013)$ \\
\hline Country Effects: & fixed & none & fixed & none \\
\hline Time (Period) Effects: & none & none & none & none \\
\hline $\mathrm{N}$ & 34 & 32 & 70 & 51 \\
\hline$R^{2}$ & 0.859 & 0.259 & 0.762 & 0.061 \\
\hline
\end{tabular}

\begin{tabular}{|c|c|c|c|c|}
\hline \multicolumn{5}{|c|}{$\begin{array}{l}\text { Table A6.4 Gini Coefficient on FDI/GDP Ratio, Lagged Labor Productivity per } \\
\text { Worker, Employment Protection }\end{array}$} \\
\hline & & & & \\
\hline & \multicolumn{2}{|c|}{ Pre-IT/globalization Era } & \multicolumn{2}{|c|}{ IT/Globalization Era } \\
\hline & Level & Delta & Level & Delta \\
\hline \multirow[t]{2}{*}{ FDI/GDP Ratio } & 0.013 & $0.256 * *$ & $0.074^{* * *}$ & -0.000 \\
\hline & $(0.014)$ & $(0.110)$ & $(0.013)$ & $(0.080)$ \\
\hline \multirow[t]{2}{*}{$\begin{array}{l}\text { Lagged Productivity per } \\
\text { Worker }\end{array}$} & $-0.188 * * *$ & -0.302 & 0.037 & -0.334 \\
\hline & $(0.003)$ & $(0.193)$ & $(0.051)$ & $(0.224)$ \\
\hline \multirow[t]{2}{*}{ Employment Protection } & $-0.201 * * *$ & $-0.180 * *$ & $0.021 *$ & 0.001 \\
\hline & $(0.002)$ & $(0.067)$ & $(0.015)$ & $(0.011)$ \\
\hline Country Effects: & fixed & none & fixed & none \\
\hline Time (Period) Effects: & none & none & none & none \\
\hline $\mathrm{N}$ & 33 & 31 & 70 & 51 \\
\hline$R^{2}$ & 0.873 & 0.318 & 0.762 & 0.074 \\
\hline
\end{tabular}




\section{Appendix VII. Capital-Augmenting Technological Progress}

Constant returns to scale Cobb-Douglas production function $Y=A K^{\alpha} L^{1-\alpha}$ cannot explain changes in labor and capital shares, since it is based on the assumption of constant factor shares in the national income. This means that technology shocks $(A)$ cannot affect the income shares going to capital and labor. To explain movements in labor and capital shares, we use a CES production function. (See also Ripatti and Vilmunen,2001).

A production function with capital-augmenting technological progress can be written as:

$$
Y=F(K, L)=\left[\alpha(A K)^{(\sigma-1) / \sigma}+(1-\alpha) L^{(\sigma-1) / \sigma}\right]^{\sigma /(\sigma-1)}
$$

$Y, K$, and $L$ are output, capital stock, and labor stock,. and $\sigma$ is the elasticity of technical substitution between capital and labor.

$$
\begin{aligned}
& \text { Capital's share }=\text { KShare }=K^{*} M P_{K} / Y=\alpha A^{(\sigma-1) / \sigma}(K / Y)^{(\sigma-1) / \sigma} \\
& \text { Labor's share }=\text { LShare }=L^{*} M P_{L} / Y=1-\text { KShare }=1-\alpha A^{(\sigma-1) / \sigma}(K / Y)^{(\sigma-1) / \sigma} \\
& \partial L \text { Share } / \partial(K / Y)=-\alpha(\sigma-1 / \sigma) A^{(\sigma-1) / \sigma}(K / Y)^{-1 / \sigma} \\
& \partial L \text { Share } / \partial A=-\alpha(\sigma-1 / \sigma) A^{-1 / \sigma}(K / Y)^{(\sigma-1) / \sigma}
\end{aligned}
$$

Movements in capital and labor shares depend on the nature of input substitutability parameter $\sigma$ and capital-output ratio. If labor and capital are technical complements, then $\sigma$ $<1$, capital share will decrease, and labor share will increase, as $\mathrm{K} / \mathrm{Y}$ increases. If, on the other hand, labor and capital are technical substitutes, then $\sigma>1$, labor's share will decrease as $K / Y$ increases.

Similarly, assuming $K / Y$ is constant, an positive technology shock $A$, will increase capital share and decrease labor share as long as $\sigma>1$. 


\section{References}

Acemoglu, D., 2000, "Labor- and Capital-Augmenting Technical Change," NBER Working Paper No. 7544 (Cambridge, Massachusetts: National Bureau of Economic Research).

Aisbett, E., 2005, "Why Are the Critics So Convinced That Globalization Is Bad for the Poor?” NBER Working Paper No. 110066 (Cambridge, Massachusetts: National Bureau of Economic Research).

Bentolila, S., and G. Saint-Paul, 2003, "Explaining Movements in the Labor Share," Contribution to Macroeconomics, Vol. 3, Issue 1 (Berkeley, California Berkeley Press).

Bhagwati, J., 2004, "In Defense of Globalization” (New York: Oxford University Press).

Blanchard, O., 1997, "The Medium Run," Brookings Papers on Economic Activity; 2, Brookings Institution, pp. 89-158.

Choi, M., 2001, “Threat Effect of Foreign Direct Investment on Labor Union Wage Premium," Working Paper Series No. 27, Political Economy Research Institute, (University of Massachusetts at Amherst).

Crotty, J., and G. Epstein, 1996. "In Defense of Capital Controls," Socialist Register, pp. 118-149.

Deardorff, A.V., 2003, “What Might Globalization's Critics Believe?” World Economy, Vol. 26, pp. 639-58.

Dollar, D., and A. Kraay, 2001, Growth Is Good for the Poor (Washington: World Bank).

Harrison, A., 2002, “Has Globalization Eroded Labor's Share,” (unpublished; University of California at Berkeley).

— Journal of Development Economics Vol. 59, pp. 125-54.

International Monetary Fund (IMF), 2002, World Economic Outlook, September (Washington).

Poterba, J., 1997, “The Rate of Return to Corporate Capital and Factor Shares: New Estimates Using Revised National Income Account and Capital Stock Data,” NBER Working Paper No. W6263, (Cambridge, Massachusetts: National Bureau of Economic Research).

Ripatti, A., and J. Vilmunen, 2001, "Declining Labour Share-Evidence of a Change in the Underlying Production Technology?” Bank of Finland Discussion Papers (Helsinki). 
Rodrik, D., 1997, Has Globalization Gone Too Far? (Washington: Institute of International Economics).

, 1998, "Globalization, Social Conflict and Economic Growth," World Economy, Vo. 21, pp 143-67. 